\title{
ARBITRATION PROCEDURE COMPARED WITH COURT LITIGATION IN PATENT CONTROVERSIES
}

\author{
JoHN F. ROBB* \\ The question treated herein may be concisely put as follows: \\ Is the procedure of arbitration adaptable for the settlement of patent litigations?
}

I

\section{General Discussion}

To appraise properly the possibilities of the usefulness of arbitration for settling litigable matters affecting patents, some understanding of the general nature of ordinary controversies involving patents should be had.

Disputes involving patents may generally be placed under three or four classes.

The first and most important type of patent litigation is the infringement suit. That is to say, a person or concern owns a patent, and another, without license, is making, selling, or using the invention of the patent, as claimed therein, creating a situation of infringement. To enjoin such infringement and recover damages therefor, a suit in a federal court is necessary, if court procedure is to be availed of, for under the federal statutes patent enforcement is exclusively within the jurisdiction of the United States courts. ${ }^{1}$

The issues in the patent infringement suit are twofold. The validity of the patent must be maintained in the trial of the suit, and a claim or claims of the patent must be shown to be infringed, if the patent owner is to succeed.

The second class of litigation over patent rights properly to be considered in order of importance involves the determination of priority of invention between rival claimants for patents who are applicants in the Patent Office, or between an applicant claimant and a patentee claimant whose patent has been issued. This species of litigation is known as a Patent Office Interference. ${ }^{2}$ It is notable that the first determination of the issue of priority between the rival claimants is made by the Board of Interference Examiners of the Patent Office, composed of three judges. From this Board, appeal may be taken to the Court of Customs and Patent Appeals, at Washington. ${ }^{3}$ Instead of such appeal, by statutory procedure, ${ }^{4}$ the interference proceeding may be transferred by a losing applicant from the Patent Office, after

- LL.B. I902, LL.M. 1903, National University; M.P.L. I904, Columbian (now George Washington) University. Member of the United States Supreme Court, District of Columbia, and Ohio bars. Author, Patent Essentials for the Executive, ENGineer, LawYer, and Inventor (1922) (2d ed. 1928); A Conplete Program for the Improvenent of the U. S. Patext LAw System (awarded Second Prize of the Linthicum Foundation of Northwestern University, I930).

${ }_{1} 28$ U. S. C. \$r338a (Supp. 1950).

${ }^{2}$ Rev. STAT. $\$ 4904$ (1875), 35 U. S. C. $\$ 52$ (1946).

${ }^{3}$ REv. StAT. \$491 I (1875), 35 U. S. C. \$59a (I946).

-Rev. Stat. $\$ 4915$ (1875), 35 U. S. C. $\$ 63$ (1946). 
decision by the Board of Interference Examiners, to a United States district court empowered upon a trial de novo to review the decision of the Board, for affirmation, or revision in favor of a losing applicant claimant. If the losing applicant under the decision of the Interference Board is adjudged by the court to be entitled to the patent priority, the court may order the patent to be issued to him.

The decisions in Patent Office Interferences by the Interference Board of Examiners and the Court of Customs and Patent Appeals are considered to be administrative decisions only, and are therefore not finally determinative of the issues involved, to the extent that the issues become res adjudicata. Indeed, the decision of the United States district court in a patent interference transferred to such court ${ }^{5}$ is not conclusive save as between the parties, even if affirmed on appeal to a court of appeals, because an infringement suit based upon a patent which has been issued to the successful party in an interference proceeding can be litigated in regard to the question of priority of invention that was previously solved in favor of the patentee of the patent in a suit. ${ }^{6}$ The inconclusiveness and endlessness of interference proceedings as above generally indicated will be adverted to later herein, in discussing the desirability of using arbitration for such proceedings.

Also, it is notable in regard to interference proceedings, that they generally involve very costly, time consuming, and complicated interlocutory motions. Not infrequently, one-third of the time occupied in the procedure of the whole interference is taken up by the interlocutory proceedings.

The third class of litigation over patent rights to be dealt with is litigation pertaining to contracts involving patents. This litigation may take different forms, including obtaining specific performance of a contract or declaration of the rights of parties under the contract. Payment of royalties may be the objective of the suit. Assignment of patent rights may be sought under a license or patent assignment agreement.

I do not think there has been much difference of opinion regarding the fact that arbitration is quite applicable to the enforcement and interpretation of licenses or other agreements. The questions existing are very largely those involving the law of contracts, and arbitration is quite adaptable to the decision of such questions to obtain substantially the same satisfactory results as have been achieved generally in arbitrating ordinary commercial contracts.

The fourth and final class of disputes over patents comprehends disputes between two patentees who own patents covering the same invention. This is a somewhat unusual situation, but arises when an applicant for a patent is placed in interference with the patentee of a patent. If the applicant is awarded a judgment of priority of invention, his patent is issued and there exist two conflicting patents. Occasionally two patents for the same general invention are inadvertently issued.

To deal with the above situation, either patentee may resort to a federal court

'Under Rev. Stat. \$4915.

- Radio Corporation of America v. Radio Engineering Laboratories, 293 U. S. I (1934). 
under a special enabling statute, ${ }^{7}$ to obtain a decree canceling or invalidating the patent conflicting with his own. No further reference need be made herein to this type of patent dispute. It does not in any way lend itself to settlement by arbitration since a United States court judgment must be handed down in order to cancel a patent once granted, and an arbitration award cannot provide the required remedy under any conditions.

I therefore deal here primarily with patent controversies comprising those relating to infringement of patents, and those to determine the question of priority of invention.

With the foregoing background familiarizing the reader with most common types of patent litigation, a final observation may be made in respect to the expense of such litigation. Quite frequently an infringement and validity suit, under which may be classified also declaratory judgment suits under the provisions of special federal statutes affecting the same matters, may run along from the time of filing suit for a period of one and a half to three years before trial. Then after trial the losing party has the right of appeal to the circuit court of appeals having jurisdiction. Much time is usually consumed in the early stages of the suit in interlocutory motions such as those for obtaining discovery under the Federal Rules of Civil Procedure. Like most litigations, patent suits are expensive luxuries. Since expert testimony is usually required in a patent suit, an additional burden is placed upon the litigants who must present and/or meet the expert testimony at the trial. To suggest that the avoidance of the large expense of a patent infringement suit is a desideratum of importance, is superfluous.

In dealing with the situation of patent infringement and the usual suits based thereon, in relation to the availability and advantages of the use of the arbitration method of settlement, the desirability and feasibility of arbitration must depend somewhat upon the attitudes of the opposing parties dealing with the infringement. As a general thing, of course, the arbitration settles a controversy as between the directly involved parties only, since a decision in the case of arbitration may not ordinarily be employed for any other controversy, unless the contract for arbitration so stipulates. A decision of a federal court adjudging a patent valid and infringed, however, is frequently a basis for grant of a preliminary injunction against third parties, an advantage not derived from arbitration awards.

As regards the court procedure for infringement suits, it is of course an important advantage derived by the owner of the patent, or the party contesting the validity of the patent, that the decision of the issue of infringement and validity shall be established as a precedent, for possible acceptance by other courts, by comity. The importance of this aspect of court procedure in infringement suits, as compared with arbitration procedure, is somewhat lessened, I believe, because even in infringment suits the parties directly involved often have little interest in the outside public enjoying the possible results of the litigation. That is to say, a party litigant

${ }^{\tau}$ Rev. Stat. $\$ 4918$ (1875), 35 U. S. C. $\$ 66$ (1946). 
(defendant) in an ordinary infringement suit, who maintains successfully that the patent on which he is sued is finally invalid, throws the invention of the patent open for use by the general public. If the matter of infringement were litigated by arbitration procedure, this result would not be obtained, but the successful party maintaining the patent invalid, or not infringed, would be freed of the burden of the patent and the claim of infringement, whereas the general public would still be required to pay tribute to the patent until such time as an open court contest invalidated the patent, or resulted in a decree of non-infringement. From the angle of ordinary commercial competition, it is to the interest of a party successfully maintaining an arbitration procedure, that a patent cannot be used against him to maintain infringement, for the patent to be still available by the owner against others, until the patent is invalidated by a court of law.

The foregoing only illustrates that in infringement causes there are different angles of approach to the situation of advantages or disadvantages of having recourse to arbitration, or court procedure, solely from the standpoint of what may be the aftermath of the litigation in relation to the involved parties, and outsiders.

Treating another phase of the ordinary infringement suit, there has been the view that the questions of validity and infringement of patents are so complicated, involving not only questions of law but factual questions as well, that arbitrators in an arbitration proceeding would not ordinarily be capable of handling or properly disposing of these questions. I have never believed that this objection was well founded. Federal courts are in reality layman judges called on to determine many technical questions of infringement and validity of patents when these are raised in court litigation. Early in the experience of such federal judges, as regards patents, most of them are lacking in training in patent law, much after the manner of ordinary laymen, though as years go on, many such judges become very expert in patent litigation.

It is not believed, therefore, that objection to the employment of arbitration in patent infringement suits may be considered well taken when based merely on the ground of possible incapacity of the arbitrator. In fact, if a board of three arbitrators is used, at least one of these may be selected because of having a certain knowledge or experience in patent law, which would enable him to guide and assist the other arbitrators in arriving at mutually agreed upon final conclusions equally as accurate and legal as those obtainable from most federal judges.

It is reiterated that the cost of patent litigation is a tremendous burden upon the litigating parties. It is so heavy in many instances that it is often impossible for individual patent owners to undertake, and even corporations of considerable size have found the expense so great that they are very slow indeed to embark upon patent law suits that frequently run for many years before final adjudication. Moreover, in this country the unique condition exists that patents may be litigated in one circuit of the ten federal circuits of the United States to a final decision, and then re-litigated in a separate or different circuit, a procedure that is shocking to 
anyone having a fair sense of efficiency. This alone makes attractive any reasonable substitute legal procedure that may settle patent controversies between directly interested parties, with expedition and less expense.

I think I should emphasize one thing at this point. If the parties who are to become involved in patent infringement litigation believe that the settlement of the issues in the litigation should be delayed as long as possible, and propose to implement such belief, recourse to court adjudication is the complete answer. If the arbitration mode of settlement is selected, results in the way of relatively prompt determination of the rights of the respective parties, at a minimum of expense, will be readily achieved, so that the elements of delay and re-litigating may be entirely eliminated for all practical purposes.

It is worthy of note also, at this time, that it is quite probable that one reason why arbitration is not availed of more frequently in patent litigation, is due possibly to the unfamiliarity of the general run of patent trial lawyers with the mechanics of arbitration. Most of such lawyers have derived their main experience in litigation from court procedure, and following that procedure is a course of least resistance so far as their experience is concerned. But upon test, they will find that arbitration as carried out today will involve nothing new to them so far as the mechanics of the trial procedure are concerned.

\section{II}

\section{Patent Arbitration in Practice}

Without, at this time, dealing with certain aspects of compelling and enforcing arbitration in the kind of controversies herein discussed, I wish to treat a highly important arbitration case in which I served as counsel, as a fait accompli, and not from the standpoint of what might be characterized as a possible procedure in the field of arbitration. My views herein expressed are based on what has been done in patent arbitration, not what might be done.

A. Facts and Circumstances Giving Rise to the Arbitration Case Discussed

A large foreign corporation, perhaps the largest in its field, was the owner of a large number of patents, certain of which it claimed were infringed by many American manufacturers in the same field (aerodynamics). Two of the group of foreignowned patents were deemed of highly crucial protection. The American manufacturers were all members of an association of a nature common in this country.

The patent owner referred to, dealing with and soliciting the cooperation of this Association, proposed:

First, that the issues of validity and infringement of the two crucial patents be arbitrated.

Second, that the accused infringing companies consolidate as one in the arbitration, and defend against these two patents in one general cause or procedure.

Third, that if the patent owner succeeded in the arbitration, it would license the accused infringers under the various patents owned; if it failed to sustain its position, the accused infringers would not be otherwise attacked. 
Fourth, that the tribute (royalties) the infringers should pay under the patents should be pre-set by the arbitration agreement, and followed, if the patent owner made good its claims of validity and infringement.

After considerable preliminary negotiation, the terms offered as above generally outlined were deemed acceptable by some eight of the alleged infringing concerns, among which were some of the largest manufacturers in the United States, and an arbitration contract was duly drawn up and signed.

Thus eight potential patent law suits were combined into a single arbitrable litigation; this of itself was obviously no small accomplishment.

The arbitration agreement included a license agreement, the patent owner being of course the licensor, and the alleged infringing parties the licensees. The rules of the American Arbitration Association were stipulated as controlling all proceedings.

Certain provisions of the agreement provided that the board of arbitration should be composed of one member selected by the patent owner (licensor), another chosen by the prospective licensees (alleged infringers), and a third member chosen by the first two, a common method of selection of arbitrators. The members actually chosen consisted of a university professor versed in the special technical art to which the patents of the contract related, a very able patent lawyer who was chosen by the prospective licensees, and a retired Rear Admiral of the United States Navy, selected by the two first arbitrators and constituting the Chairman of the Board.

The agreement also, among other provisions, set up the patent owner and the patents involved in the controversy; provided for voluntary acceptance of the agreement by the alleged infringers; carefully set forth the rights granted and reserved; provided in advance, as before indicated, for the amount of royalties to be paid upon the arbitrators' award; and also contained a provision that if any one or more of the patents involved were later invalidated by a United States court of original jurisdiction, the licensees should be privileged to cease paying royalties on the patent so held invalid.

This brings me to the portion of the agreement applicable directly to the arbitration procedure, something which was treated at length so as to avoid any misunderstanding.

In this connection the payment of royalties under the patents alleged to be infringed by the prospective licensees was conditioned upon the settlement of two main issues by the arbitration board. These issues were, first, the validity and scope of the patents involved; and, second, whether or not the products of the prospective licensee (alleged infringer) were an infringement of one or more of said patents. The first issue was to be decided by a special hearing in which all prospective licensees (infringers) could participate, since it must be preliminarily established that the patents were valid and of some scope, for otherwise there would be no necessity to consider questions of infringement. The second issue of the infringements by the various licensees was to be settled by separate hearings for each licensee, dependent upon resolving the first issue in favor of the patent owner. 
In the determination of the question of infringement, as prescribed by the contract, much of the usual and time-consuming procedure of ordinary suits to obtain discovery regarding this matter was eliminated by the mere provision in the contract requiring the accepting licensees and possible infringers to furnish to the Board of Arbitration, subject to the inspection by the patent owner and/or its attorneys, such information regarding their manufactured constructions as was deemed necessary by the Board of Arbitration to enable determinations of the questions involved in the proceeding. The latter, of course, were primarily the questions of infringement.

The agreement made further provisions that the decisions of the arbitration tribunal should be final, and if applicable to later different designs manufactured by the licensees or alleged infringers, should be binding upon the parties to the agreement as long as it remained in effect. In this manner possible future infringement situations were covered. It also provided that the general arbitration procedure should comply with the arbitration law of New York State.

\section{B. Preliminary Proceedings of the Arbitration}

For comparison with ordinary trial procedure in the courts, the mechanics of the trial of the issues in this case are of special interest. It is well known that as a general rule, and as a result of experience, "arbitrators are not bound by the rules of evidence, and because parties are permitted, before arbitrators, to tell their story and the facts in an informal fashion, a controversy may be tried before arbitrators in anywhere from one-fifth to one-tenth of the time required in court." I think, generally speaking, that the foregoing statement applied to this case which I am discussing, for, notwithstanding the large number of counsel representing the eight or nine different licensees, the alleged infringers, there was relatively little objecting during the whole progress of the trial.

Obviously, before the cases of the respective parties could be presented at the hearing, two things of importance had to be done.

The first task of the Arbitration Board, after its selection, and at its first meeting, was to draw up the rules of patent arbitration procedure to be followed by the parties, since these rules were to govern the parties to the proceeding and the manner of presentation of proofs. The rules were in some phases such as would be used in ordinary arbitration cases, and, generally summarized, established a definition of the parties to the proceeding, appointed a chairman of the board, provided for the contingency of incapacity of any arbitrator, selected a secretary, indicated the times of hearings and informal meetings of the Board, mode of sending notices to the parties, the number of arbitrators constituting a quorum, the order of the proceedings involving the presentation of proofs, provisions for custody of the records and data submitted and inspection thereof, mode of closing the hearings, method of making the awards, immunity of the arbitrators, and nature of the evidence to be

\footnotetext{
${ }^{8}$ Popkin, Arbitration Benefits the Lawyer, 6 ARB. J. I13, II4 (1942).
} 
received as to the character of copies of records, patents, and extracts from textbooks and publications.

It was necessary that the defending parties or prospective licensees should file the data or disclosure of their alleged infringing constructions with the Arbitration Board. A time was fixed for this and due compliance with the requirement for submission of the data took place.

With the filing of the complaint by the patent owner and the answer incorporating the defenses of the eight prospective licensees allegedly infringing the patents in controversy, the case was brought to issue.

All parties were required first to submit their respective cases in reference to the common issue for all, that of determining the validity and scope of the patents, to enable a decision to be made upon this issue, closing this portion of the case.

\section{Trial of the Issues (Validity)}

Following the opening statements, the patent owner proceeded to take its proofs, which involved the offering in evidence of the patents, the explanation of the patented inventions by a renowned technical expert in the field of invention to which the patents related, and complete treatment of the history of the file wrapper contents of the patents as they affected the questions of validity and scope. I followed this last course because the defenses set up included estoppels in the file wrappers of the litigated patents and had to be met sooner or later.

As their case, the prospective licensees collectively offered in evidence the prior art and their interpretation of the file wrapper histories of the patents, including expert testimony in regard to the relation of the prior art to the alleged infringed patents.

Thereupon, the patent owner offered rebuttal testimony. The presentation of lengthy briefs of authorities by both parties closed the trial of the first issues of validity and scope.

The Arbitration Board then suggested to the opposing parties that each party present an outline of a proposed award and findings for the Board to arrive at, based upon the view of each in the light of the evidence presented at this first hearing. When this was done, the Board took the case under further advisement and arrived at a unanimous decision in respect to the validity of the patents and their scope.

The decision was unlike the usual run of court decisions in a very tangible respect. It established conclusions as to each patent involved, determining the scope of the claims as not including certain definite constructions (which were specified in a large number of summary paragraphs). In other words, the effect of the decision was that the patents were valid but did not include in their scope certain types of constructions.

I must say this holding created some difficulty for all parties concerned because the criteria on which the Board based its exclusion of the particular constructions 
as not within the effective scope of the patents was not at the time revealed. Nevertheless, in the ultimate analysis no party suffered, in my judgment, as a result of the foregoing situation.

The patents having been favorably adjudicated, therefore, as to validity and scope in such a manner as to render necessary the carrying forward of the further procedure to determine the questions of infringement of the individual constructions of the various prospective licensees (alleged infringers), the latter issues were next made the subject of the arbitration procedure.

\section{Trial of Issues (Infringement)}

At this stage of the proceedings the trial actually divided its operation into the individual cases of the infringers and so need for combined action on the part of the infringers ceased. As each separate infringement case was called up, the evidence of the particular infringements of the defendant, so to speak, was offered, having been voluntarily filed and previously checked on behalf of the patent owner. Expert evidence was taken, where desired, on behalf of both parties, and the case against the particular party submitted for decision.

Upon completion of the Board's study of the proofs offered on each infringement, an award was made in favor of or against the alleged infringing party. The award was the final conclusive decision affecting the issues.

In some instances where several infringements were alleged by the patent owner against one party, the award rendered by the Board was in favor of the patent owner as to one or more constructions, and against the patent owner as to one or more constructions alleged to be the infringements.

The procedure of the hearings for determination of the infringements was carried forward expeditiously and again little or no time was involved in objections, because the patent owner accepted the proffered evidence of the alleged infringer's constructions, originally presented under the contract provisions. The patent owner previously had ample knowledge of just what each alleged infringer was producing in the commercial field, and the infringer faithfully reported this, so no difficulty was incurred in this connection. The periods of time consumed in trying the infringement issues for the different parties were, of course, different because of the variation in the number of infringements alleged. In an instance or two a single day was sufficient to settle the infringement and enable the Board to make its award, whereas in other instances the issues required somewhat longer periods to determine.

Different attorneys, generally, represented, the different defending parties.

\section{E. Final Award}

When the hearings were all completed, the individual awards having been made with record notice to the parties involved, the Board drafted a final award setting up a complete listing of the various awards rendered in favor of or against the parties.

No opinion was rendered in reference to any award explaining how the award 
was arrived at, though at the conclusion of the hearings, upon the special request of all counsel, the Chairman of the Board did make an explanation for the purposes of the record, indicating the views of the Board somewhat more positively, as distinguished from the original negative indication of constructions excluded from the scope of the patents, and revealing what was considered in the various constructions alleged to infringe that brought a particular construction or constructions within the scope of the patents. Such an explanation was necessary, obviously, in order to determine any possible future infringements that might have to be adjudicated by reason of new structures being put on the market, or contemplated, by alleged infringers or prospective licensees.

\section{F. Results of Arbitration}

The arbitration resulted, of course, in awards favorable and adverse to nearly all parties concerned. Effectively speaking, eight patent suits were adjudicated in respect to approximately twenty-eight different constructions of infringing machines. As in all litigation, it was impossible for both parties to win. The awards finally arrived at were about equally divided between the parties.

I have been counsel in many patent suits, the trials of which have ranged from a day or two days to six weeks, and my experience indicates that if this arbitrated litigation which $I$ have described in this paper had been the basis of an ordinary patent suit in respect to the alleged infringements of each defending party, the expense involved would have been at least four times as great. That is to say, I calculate that the expense of two of the infringement causes involved in this arbitration, and possibly even one of the heavier cases, had they been presented by ordinary court suits, would have been approximately the same as that involved in trying the issues in the eight different causes that were arbitrated. In this connection I take into consideration only the expense of the trials in the United States district court and not the expense that would have been involved in appeals according to ordinary procedure which would have been about one-third again as much as the trial expense. The tremendous saving in the cost of the whole litigation becomes self-evident from the foregoing.

However, there is another angle, and that is the time consumed. Necessarily, considerable preparation and study were involved on the part of counsel prior to the starting of the arbitration hearing on the patent validity and scope issues, which occupied perhaps four or more days, as well as respecting the various infringement situations. Hearings were then recessed for two or three days pending the decision of the Board on the first issues. Then the hearings were resumed on the final infringement issues, and occupied approximately eight or ten days. This ended the whole trial in reference to all parties concerned, and final awards were of record in the proceedings within two or three days after the end of the hearings, being merely a summary of the individual awards handed down during the hearings.

It should be remarked, however, that one of the greatest time-saving factors in- 
volved in arbitration of the class herein discussed lies in the fact that the arbitration may proceed at any time as soon as the arbitration agreement is formulated and accepted. It does not have to wait its turn among hundreds of other cases in the crowded calendars of the courts as do ordinary litigated cases, sometimes making for a year or years of delay.

I estimate that the time consumed, had the eight cases separately gone to trial in the United States courts, would have been at least four times that actually taken by the arbitration proceeding. This is a decidedly variable factor, however, depending on the opposing counsel involved and their methods of trying law suits.

I am convinced that while this arbitration proceeding involved some unusual conditions and some slight difficulties incident to the unfamiliarity of two of the arbitrators with patent procedure, the disposition of the arbitrated causes was expeditiously effected with a tremendous saving from the time-consuming and expense standpoints, and ended litigation in a period of twenty days of direct trial work, which litigation might have continued over five to ten years, if the cases had been presented individually in the United States courts.

I should also make one more special comment. In this whole arbitration, as described, a phase of proofs most common in patent suits was not involved. Nearly every patent case of the kind discussed requires adducing of evidence of prior uses on which invalidity of a patent is urged. This class of proofs is time-taking and usually prolongs a trial very considerably. Fortunately, in this arbitration, the entire prior art as developed was found in prior patents and publications; henceand this was somewhat unusual, I must concede-the time factor on the validity hearing was below the normal. Therefore, had prior use testimony been required, the comparison as regards length of the proceeding, as respects the court trial periods, might be a little less favorable. The saving, in any event, would have been tremendous.

In difficult technical, chemical, or even complicated mechanical patent cases, I can see the desirability of incorporating in the arbitration agreement a stipulation giving the arbitrators the privilege of consultation with independent specially qualified experts to decide especially technical matters, but this would not detract from the benefit of the general procedure.

\section{III}

\section{Patent Interference Litigation}

Discussing the above subject as a class of litigation where arbitration may be employed, I wish to say that such procedure has been and is now being used to advantage by patent attorneys.

Interferences are prolonged contests. When, as is most common, they involve two or more applications for patents, they may run along for years. One of my own interference cases took eight years to reach the final decision, at very large 
expense to the parties. Not a few interference cases are on record which have required six to ten years to terminate. ${ }^{9}$

Obviously, bearing in mind the length of time of pendency of interference causes, a chief difficulty arises in the delay created in obtaining issue of the patent or patents on the involved applications. This delay is highly detrimental to the public, eliminating consideration of the more personal interests of the parties, one of whom may suffer irreparable damage by delay in obtaining his patent.

In addition, attorneys experienced in interference litigation well know that the procedure is inconclusive of the issue of priority, for reasons previously touched upon.

Recognizing the foregoing conditions, able counsel in patent law frequently advise a settlement of interferences, sometimes to the disadvantage of the party senior on the records of the Patent Office, rather than to pursue a futile and unending course of litigation. Leading attorneys have viewed patent interference procedure, as now framed, a "cancer" in the operation of the patent system.

Arbitration of patent interferences is a ready and suitable recourse to adopt, and lends itself to satisfactory settlement. Customarily, it may only require that the attorneys for the parties get together, compare affidavit-supported proofs, and decide in view thereof which party should succeed. Such arbitration, implemented by stipulation between the parties that the party denied the award of priority shall file either a disclaimer of the interference issues, or a concession of priority of the subject matter of the issues to his opponent, has succeeded time and again. Outside arbitrators may be employed, of course, and may well be disinterested patent lawyers who have full acquaintance with the interference law and practice.

Ofttimes the arbitration agreement may include the requirement that a winning party, in consideration of the procedure adopted, shall license the losing party under the conflicting issue subject matter, all to the end of expeditious disposition of the litigation.

Finally, however, I reiterate what has been said before in connection with court litigated infringement suits: if delay is the objective, an interference party may well decide to contest the interference under the Patent Office rules and delayed results will readily be achieved.

\section{IV}

\section{Enforcing Arbitration of Patent Controversies}

I do not attempt herein to survey exhaustively the legal phases of enforcing arbitration in matters affecting the validity and infringement of patents, but this paper would not be complete without dealing with this subject at some length, as well as with arbitration agreements generally involving patents.

Notwithstanding early decisions to the contrary handed down mainly by lower

- See case cited note 6 supra. 
federal courts, ${ }^{10}$ the interpretation of the Federal Arbitration Act $^{11}$ has been clarified in the last decade to an extent warranting the view that United States courts have ample power to compel performance of arbitration agreements involving validity and infringement determinations, usually a function, exclusively, of such courts.

It is to be observed preliminarily that as to contracts of patent licensing, agreements to assign patent rights, and the like, involving arbitration terms, jurisdiction may lie as to the subject matter, only in the state courts, unless by reason of diversity of citizenship between the parties a federal court may be vested with such jurisdiction. Thus, in some circumstances, patent arbitration agreements, repudiated prior to making of awards thereunder, may come under the sole jurisdiction of state courts, with an important exception-namely, those involving the validity and infringement of patents.

Now as regards the validity and infringement of a patent, under the Judicial Code, ${ }^{12}$ only federal courts have jurisdiction to establish these matters except to such extent as such jurisdiction may be waived by the parties to arbitration agreements as contemplated within the scope of the Federal Arbitration Act.

Discussing generally the Federal Act, the matter of constitutionality appears settled as of the present time. ${ }^{13}$

Referring to the provisions of the Federal Act, the title reads as follows:

Chapter 213.-An Act to make valid and enforceable written provisions or agreements for arbitration of disputes arising out of contracts, maritime transactions, or commerce among the States or Territories or with foreign nations.

Irrespective of the legal status of the title of an act of Congress, there appears a clear contemplation of its scope as including "contracts" other than those of "maritime transactions" and those involving "commercc."

The first section of the Act gives definitions of what is meant by the terms "maritime transactions" and "commerce," and, additionally, excludes from the operation of the Act "contracts of employment of seamen, railroad employees, or any other class of workers engaged in foreign or interstate commerce."

Section 2 of the Act specially declares the validity, irrevocability, and enforceability of written provisions to settle by arbitration, controversies growing out of contracts of a maritime nature or involving commerce.

Section 3 is very important. It deals with suits or proceedings brought in any United States court upon any issue referable to arbitration, under an agreement in writing for such arbitration, and empowers the courts to stay the trial of the action until such arbitration has been had in accordance with the terms of the agreement, etc., including other details not relevant to this discussion. The referable issues must necessarily be those within the jurisdiction of the courts mentioned.

\footnotetext{
${ }^{10}$ Zip Manufacturing Co. v. Pep Manufacturing Co., 44 F.2d I 84 (D. Del. 1930): In re Cold Metal Process Co., 9 F. Supp. 992 (W. D. Pa. 1935).

${ }^{11} 9$ U. S. C. $\$ \$ 1-15$ (Supp. I950). ${ }^{12} 28$ U. S. C. $\$ 1338 a$ (Supp. I950).

${ }^{13}$ Marine Transit Corp. v. Dreyfus, 284 U. S. 263 (1932).
} 
The point of emphasis now made is that this section is in no way specially limited to maritime transactions or commerce agreements. It broadly includes issues (claims) in an agreement in writing, referable to arbitration, and empowers the court to stay proceedings to enable the arbitration to be consummated.

Dealing with Section 4 of the Act, we come to its arbitration-enforcing provisions.

Section 4 gives the federal courts power to enforce arbitration in behalf of a party aggrieved by failure, neglect, or refusal of another to arbitrate under an agreement in writing for arbitration. The aggrieved party may petition any court of the United States, which, save for such agreement, would have jurisdiction under the Judicial Code at law, in equity, or in admiralty, of the subject matter of a suit arising out of the controversy between the parties. The balance of the section is procedural and is not material to this discussion.

I ignore also Sections 5 to 15 of the Act as largely procedural and not controlling the scope, application, or enforceability of the arbitration.

Upon general study of the several sections above detailed as to certain provisions, including the object of Congress in passing the Act, it is difficult to see why the Act is not fully applicable to all cases which are subject to federal court jurisdiction as specified in Section 4. There may be special limitations of jurisdiction and ambiguities in the terms of the legislation, but I have been unable to see them, or the viewpoints of some of the courts which have adjudged their existence.

As respects Section 4, it seems clear also that a patent suit involving questions of validity and infringement is an action under the judicial code at law or in equity, as the terms are used in the Act. It (such suit) is, and always has been, subject to exclusive jurisdiction of the United States courts. Such suits, therefore, when the matters mentioned are the subject of an arbitration controversy, are definitely open to the jurisdiction of the federal courts for enforcement of arbitration provisions made in writing, because had the arbitration agreement not been made, the issues therein would only be determinable by United States courts.

In the report of the Committee on the Judiciary of the House of Representatives, respecting the bill which became the United States Arbitration Act in question, it was said: ${ }^{14}$

The purpose of this bill is to make valid and enforceable agreements for arbitration contained in contracts involving interstate commerce, or within the jurisdiction of admiralty, or which may be the subject of litigation in the Federal Courts... . The remedy is founded also upon the Federal control over interstate commerce and over admiralty.

That special definition and mention was made of commerce contracts and maritime transactions in Sections $I$ and 2 of the Act does not seem to warrant any necessary limitations of Sections 3 and 4 to such kinds of contracts or transactions alone.

Notwithstanding the foregoing, the view of lower federal courts in the earliest

${ }^{14}$ H. R. Riep. No. 96, 68th Cong., Ist Sess. (1924). 
decisions interpreting the Act was to establish certain limitations such as those referred to above. ${ }^{15}$

In the case of Shanferoke Coal and Supply Corp. v. Westchester Service Corp., ${ }^{16}$ the Second Circuit Court of Appeals, however, decided that Section 3 of the Act was not burdened with the limitations of Sections I and 2. This was the first pronouncement to such effect, negativing the doctrine of the Zip Mfg. Co. and the Cold Metal Process cases, though not directly dealing with them. Judge Learned Hand said, as regards Sections $I$ and 2 limiting Section $3:{ }^{17}$

We are not clear that this is true; section 2 defines those contracts which it makes "valid, irrevocable, and enforceable," and no doubt such alone are within section 4 .

This last statement respecting Section 4 was clearly obiter and was included without any detailed treatment of the various provisions and history of the Federal Act as they might relate to Section 4 .

But the view expressed has been referred to in later decisions of United States district courts and given certain acceptance. On this account for many years the status of Section 4 was a matter of doubt.

It does not appear in the cases thus far decided that the question of whether a controversy involving arbitration of patent validity and infringement is enforceable under the Federal Arbitration Act, has been adjudicated.

The early Zip Manufacturing Co. case indicated unenforceability, though that case was brought under Section 3 of the Federal Act on a motion to stay proceedings.

Of special interest is the case of Cavicchi v. Mohawk Manufacturing Co., 18 wherein the United States Supreme Court dismissed an appeal for want of a substantial federal question, from the highest court of New York. The case in the latter court was based on the New York Arbitration Act, ${ }^{19}$ and was brought to obtain confirmation of an arbitration award in a controversy wherein infringement of a patent was involved. ${ }^{20}$ Apparently the United States Supreme Court approved an entry of judgment by the state court in a controversy over which the federal courts would ordinarily have exclusive jurisdiction, save for the arbitration agreement.

O'Brien, in his splendid discussion on "Enforcement of Arbitration Agreements in Infringement Disputes"21 points out, however, that the arbitration award had been duly entered in the Cavicchi case, and such awards, once made, are enforceable by both the Federal Act and state arbitration acts where they exist.

Both O'Brien in his paper and Deller in an earlier discussion ${ }^{22}$ dealing in an able manner with this subject, upon review of prior adjudicated cases, arrived at the

\footnotetext{
${ }^{20}$ See the Zip Manufacturing Co. and Cold Metal Process Co. cases, supra note ro.

${ }^{10}$ 7o F.2d 297 (2d Cir. I934), aff'd, 292 U. S. 449 (I934).

${ }^{17}$ Id. at 298 .

${ }^{18}$ I 43 U. S. PAT. Q. 419, 520 (1939), 308 U. S. 522 (1939).

${ }^{10}$ N. Y. Crvil Practice ACr Art. 84, $\$ \$ 1448-1469$.

20 The validity of the patent was not in issue.

2122 J. Pat. OFF. Soc'y 289 (1940).

s2 The Use of Arbitration in Patent Controversies, 2I J. PAT. OfF. Soc'y 209 (I939).
} 
general thought that as of the time of their writings it was questionable whether an arbitration affecting patent infringement and validity would or could be enforced by the federal courts, if once repudiated by one of the parties, or by state courts (according to O'Brien) when it is borne in mind that validity and infringement matters are exclusively within the jurisdiction of the federal courts.

But the writers above noted were certainly constrained to reach their views in the light of then decided cases, especially Zip Manufacturing Co. and Cold Metal Process Co.

In the Zip Manufacturing Co. case, Judge Nields dealt with a contract calling for arbitration of questions of patent validity and infringement, and a motion to stay made under Section 3 of the Federal Act.

Judge Nields held that Section 3 was limited by the provisions of Section 2, and that the provision in the agreement in controversy " that the question of validity and infringement shall be determined by arbitration,' relates to a controversy involving neither commerce nor a maritime transaction . . . and therefore is not enforceable under the Federal Arbitration Act."23

The motion to stay proceedings under Section 3 was accordingly denied by Judge Nields.

In the second case noted (Cold Metal Process Co.), Judge McVicar said:24

While the act is not clear, I am of the opinion that it was the intent and purpose of Congress to limit the powers conferred by sections 3 and 4 thereof to contracts or agreements specified in section 2 , with the definitions contained in section $x$.

citing cases, including the Zip Manufacturing Co. case.

The contract involved in this case was a patent license.

Judge Nields, in the Zip Manufacturing Co. case went so far as to say:25

The determination of the status of a patent, its validity or invalidity, its infringement or non-infringement, is a matter that is inherently unsuited to the procedure of the arbitration statutes.

I am unable to agree, based on practical experience with the subject, with Judge Nields' views above expressed, and fortunately when the interpretation of the Federal Arbitration Act came to the forums of certain United States circuit courts of appeal, neither the view of Judge Nields nor the decision of Judge McVicar was sustained so far as based on an interpretation of the so-called limiting effect of Section 2 and/or Section I of the Act on Section 3.

We may next examine cases of the higher courts, in more recent years, dealing with the interpretation of the Federal Arbitration Act. Sections 3 and 4 are the sections of special concern.

The first case directly discussing and overruling the view of Judge Nields in

${ }^{28}$ Zip Manufacturing Co. v. Pep Manufaturing Co., 44 F.2d 184, 185-186 (D. Del. 1930).

24 In re Cold Metal Process Co., 9 F. Supp. 992, 993 (W. D. Pa. 1935).

${ }^{28} \mathrm{Zip}$ Manufacturing Co. v. Pep Manufacturing Co., supra, at 186. 
Zip Manufacturing Co. and the view of Judge McVicar in Cold Metal Process Co. is the decision of the Third Circuit Court of Appeals in Donahue v. Susquehanna Collieries $\mathrm{Co}_{0}{ }^{26}$ from which the following excerpts are taken:

The title of the Act suggests, though of course it does not compel, the conclusion that the provisions of the statute are applicable to three kinds of things: (I) Contracts, (2) maritime transactions, and (3) commerce, interstate and foreign. The first section defines maritime transactions and commerce. Then the second section proceeds to lay down a rule of substantive law regarding the validity of an agreement for arbitration in case of any maritime transaction or contract evidencing a transaction involving commerce. Congress was here making a rule concerning subject matter within its own constitutional legislative authority. It was not seeking to confer validity to arbitration agreements generally, a matter outside the scope of federal powers. Instead it picked out two important classes of transactions within the federal legislative domain and declared the effect of arbitration clauses in agreements concerned therewith.

Then in $\S_{3}$ the statute deals with the conduct of suits in federal courts, again a subject matter of congressional power. The language becomes general: "any suit or proceeding," upon "any issue referable to arbitration under an agreement in writing for such arbitration" are the words. Congress is not limited, in legislating as to law suits in federal courts, to those suits involving matters where the substantive rights of the parties may be controlled by federal legislation. The generality of the language used in the statute does not suggest any self-imposed limitation. Nor do we think that the "congressional approval of arbitration" should be so limited by implication, by a grudging type of construction carried down from the days of judicial hostility to all arbitration agreements. We think it clear that the provisions of $\S_{3}$ are not to be limited to the specific instances dealt with in $\$ 2$.

This view finds support in the discussion by Judge Learned Hand in Shanferoke Coal \& Supply Corp. of Delaware v. Westchester Service Corp., 2 Cir. 1934, 70 F.(2d) 297, 298, affirmed I935, 293 U. S. 449, 55 S. Ct., 3 39, 79 L. Ed. 583 . We find no evidence that the dictum is weakened by subsequent decisions in other questions arising under the Act in the Second Circuit. Indeed it seems to us to be strengthened by the holding that the instances where a stay may be granted under $\$_{3}$ are not limited to those situations where arbitration may be compelled under $\$ 4$. On the other side, there is a dictum supporting the limitation in a decision upon a motion to dismiss a petition for the appointment of arbitrators in the Western District of Pennsylvania, language of like effect in the Middle District, and a considered discussion supporting the limitation by Judge Nields in the District of Delaware. As indicated above, we think the Act is entitled to a construction which will accomplish its purpose, and should not be hedged about with imagined limitations, as has been done in some instances.

Here again we should not choke the arbitration process which has been given congressional approval by the fetters of earlier judicial conceptions.

It is of more than passing interest to note that the contract of arbitration forming the subject of this decision was an employment contract providing for arbitration of any difficulty or disagreement growing out of relations of employers and employees. The case involved the question of arbitration of a claim under the Fair Labor Standards Act.

${ }^{20}$ 138 F.2d 3, 5-6, 7 (3d Cir. 1943) (decided Sept. 3, 1943; rehearing denied, Oct. 19, 1943). 
This decision is clear authority for the position that Section 3 of the Arbitration Act is not limited by Section 2, re-affirming the view of the Second Circuit Court of Appeals in the Shanferoke case.

Therefore, it is clear from the Donahue decision that Section 3 deals with contracts entirely outside of the sphere of those known generally as maritime transactions or contracts of commerce.

The next decision that deals with the situation above referred to as regards interpretation of the Federal Arbitration Act is that of the Fourth Circuit Court of Appeals in Agostini Bros. Bldg. Corp. v. United States, a decision handed down by Judge Parker, ${ }^{27}$ June 2, 1944. In this decision Judge Parker, for the court, quoted at length certain portions of the decision of the Third Circuit Court of Appeals in Donahue v. Susquehanna Collieries Co., which I have quoted herein. The Agostini case largely follows the views expressed in the Donahue case respecting the scope of Section 3 of the Arbitration Act.

We therefore have the Agostini case supplementing the Donahue case, and it is especially noteworthy that in the Agostini case the contract involved was not one involving either commerce or a maritime transaction. This case related to an action by the United States against a contractor to recover for labor and materials furnished in the construction of a government building.

The Agostini case was one involving the jurisdiction of the federal court, not derived from the commerce provision of the Constitution, but from a direct provision of the Constitution giving the federal courts jurisdiction of cases involving the United States. The Agostini case, therefore, has a parallel in reference to cases of arbitration contracts relating to patent rights because the jurisdiction of the federal courts in reference to patent rights does not arise out of the commerce provision of the Constitution, but arises out of the direct provision of the Constitution giving Congress power to legislate with regard to protection of inventions.

Since this decision in the Agostini case, the Fourth Circuit Court of Appeals in r948 has rendered another decision in which it deals not only with the status of Section 3 of the Federal Arbitration Act in relation to Section 2, but also the status of Section 4 in so far as this may be affected by Section 2. This case is International Union United Furniture Workers of America v. Colonial Hardwood Flooring Co. ${ }^{28}$ In this case the Fourth Circuit Court of Appeals by Judge Parker again deals with the situation of the holding by the same court in the Agostini case that Section 3 of the Federal Arbitration Act should not be interpreted as limited by the provisions of Section 2. The court refers to its previous decision in the Agostini case and then makes the following statement: $:^{29}$

The reasoning of that decision would apply equally to Section 4 and the succeeding sèctions.

${ }^{27}$ Agostini Brothers Bldg. Corp. v. United States, I42 F.2d 854 (4th Cir. 1944).

${ }^{28} 168$ F.2d 33 (4th Cir. I948).

${ }^{29}$ Id. at 37 . 
We thus have, as about the latest higher pronouncement which I have been able to locate, the interpretation of a leading circuit court of appeals that Section 3 and Section 4 of the Arbitration Act are not limited by reason of the provisions of Section 2 and Section I to cases involving maritime transactions or commerce over which the federal courts have jurisdiction.

Attention is also called to the fact that the quoted portion of the court of appeals decision in the United Furniture Workers case is an effectual holding that not only Section 4, but the succeeding Sections 5 to I5 of the Federal Act, are not limited by Section 2.

Prior to the latest decision of the Fourth Circuit Court of Appeals, above discussed, Judge Leibell, of the Southern District Court of New York, accepted the dictum of the Second Circuit Court of Appeals in the Shanferoke case suggesting limitation of Section 4 to agreements specified in Sections I and 2 of the Federal Act, as expressed by the words "no doubt such alone are within Section 4," a dictum I have already discussed. ${ }^{30}$

One of the best complete reviews of the general state of adjudicated cases dealing with the Federal Arbitration Act is found in the lengthy opinion of Judge Delehant in Wilson \& Co. v. Fremont Cake \& Meal Co. ${ }^{31}$ Judge Delehant commented particularly on the San Carlo Opera Co. case in regard to the above quoted words from the Shanferoke case pertaining to Section 4 , and stated inter alia ${ }^{32}$

So 'far as the authorities cited by counsel, or within this court's information, extend, the thought of the court of the second circuit upon the exact question being considered is reflected only in dictum, and, therefore, is no more than tentatively determinable.

In summary, therefore, it would appear that the considered holding of the Fourth Circuit Court of Appeals in the United Furniture Workers case greatly enlarges the scope of Sections 3 and 4 of the Federal Act and warrants the view that our federal courts in the future have a sound basis upon which to enforce written arbitration agreements in any United States court which, save for the agreement, would have jurisdiction of the subject matter of a suit arising out of a controversy between the parties, under the Judicial Code, at law, in equity, or in admiralty. Agreements of arbitration affecting patent validity and infringements seem clearly to be within the scope of the Federal Act, being exclusively within the jurisdiction of the federal judiciary.

${ }^{30}$ San Carlo Opera Co. v. Conley, 72 F. Supp. 825 (S. D. N. Y. 1946), $a f f d$, I63 F.2d 31o (2d Cir. 1947).

37 F. Supp. 364 (D. Neb. 1948).

s2 Id. at $378-379$. 